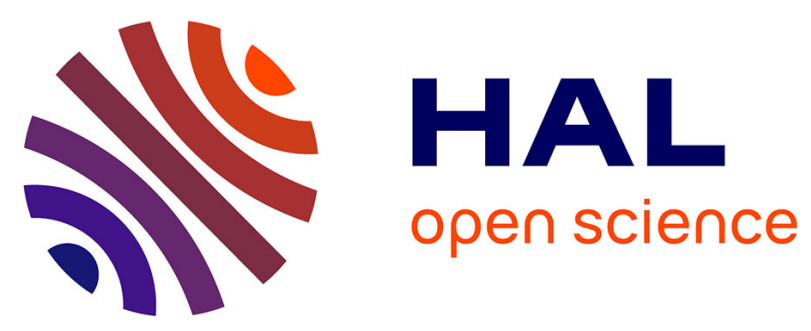

\title{
Photosynthetic sensitivity to drought varies among populations of Quercus ilex along a rainfall gradient
}

Nicolas Martin-Stpaul, Jean-Marc Limousin, Jesús Rodriguez-Calcerrada, Julien Ruffault, Serge Rambal, Matthew G. Letts, Laurent Misson

\section{- To cite this version:}

Nicolas Martin-Stpaul, Jean-Marc Limousin, Jesús Rodriguez-Calcerrada, Julien Ruffault, Serge Rambal, et al.. Photosynthetic sensitivity to drought varies among populations of Quercus ilex along a rainfall gradient. Functional Plant Biology, 2012, 39 (1), pp.25-37. 10.1071/FP11090 . hal-02648705

\section{HAL Id: hal-02648705 \\ https://hal.inrae.fr/hal-02648705}

Submitted on 29 May 2020

HAL is a multi-disciplinary open access archive for the deposit and dissemination of scientific research documents, whether they are published or not. The documents may come from teaching and research institutions in France or abroad, or from public or private research centers.
L'archive ouverte pluridisciplinaire HAL, est destinée au dépôt et à la diffusion de documents scientifiques de niveau recherche, publiés ou non, émanant des établissements d'enseignement et de recherche français ou étrangers, des laboratoires publics ou privés. 


\title{
Photosynthetic sensitivity to drought varies among populations of Quercus ilex along a rainfall gradient
}

\author{
Nicolas K. Martin StPaul ${ }^{\mathrm{A}, \mathrm{D}}$, Jean-Marc Limousin ${ }^{\mathrm{B}}$, Jesús Rodríguez-Calcerrada ${ }^{\mathrm{A}}$, \\ Julien Ruffault ${ }^{\mathrm{A}}$, Serge Rambal ${ }^{\mathrm{A}}$, Matthew G. Letts ${ }^{\mathrm{C}}$ and Laurent Misson ${ }^{\mathrm{A}}$ \\ AEquipe DREAM, CEFE CNRS 1919 route de Mende 34000 Montpellier, France. \\ ${ }^{B}$ Department of Biology, University of New Mexico, MSC03 2020, Albuquerque, NM 87131-0001, USA. \\ ${ }^{\mathrm{C}}$ Department of Geography, Alberta Water and Environmental Science Building, University of Lethbridge, \\ 4401 University Drive, Lethbridge, Alberta T1K 3M4, Canada. \\ ${ }^{D}$ Corresponding author. Email: nmartin@cefe.cnrs.fr
}

\begin{abstract}
Drought frequency and intensity are expected to increase in the Mediterranean as a consequence of global climate change. To understand how photosynthetic capacity responds to long-term water stress, we measured seasonal patterns of stomatal $\left(S_{\mathrm{L}}\right)$, mesophyll $\left(M C_{\mathrm{L}}\right)$ and biochemical limitations $\left(B_{\mathrm{L}}\right)$ to net photosynthesis $\left(A_{\max }\right)$ in three Quercus ilex (L.) populations from sites differing in annual rainfall. In the absence of water stress, stomatal conductance $\left(g_{\mathrm{s}}\right)$, maximum carboxylation capacity $\left(V_{\text {cmax }}\right)$, photosynthetic electron transport rate $\left(J_{\max }\right)$ and $A_{\max }$ were similar among populations. However, as leaf predawn water potential $\left(\Psi_{1, \mathrm{pd}}\right)$ declined, the population from the wettest site showed steeper declines in $g_{\mathrm{s}}, V_{\text {cmax }}, J_{\max }$ and $A_{\max }$ than those from the drier sites. Consequently, $S_{\mathrm{L}}, M C_{\mathrm{L}}$ and $B_{\mathrm{L}}$ increased most steeply in response to decreasing $\Psi_{1, \mathrm{pd}}$ in the population from the wettest site. The higher sensitivity of $A_{\max }$ to drought was primarily the result of stronger stomatal regulation of water loss. Among-population differences were not observed when $g_{\mathrm{s}}$ was used instead of $\Psi_{1, p d}$ as a drought stress indicator. Given that higher growth rates, stature and leaf area index were observed at the wettest site, we speculate that hydraulic architecture may explain the greater drought sensitivity of this population. Collectively, these results highlight the importance of considering among-population differences in photosynthetic responses to seasonal drought in large scale process-based models of forest ecosystem function.
\end{abstract}

Additional keywords: carbon sequestration, ecohydrological equilibrium theory, evergreen forest, Farquhar model, holm oak, hydraulic architecture, leaf gas exchange, precipitation gradient.

Received 14 April 2011, accepted 28 September 2011, published online 7 November 2011

\section{Introduction}

Water scarcity is the primary environmental factor limiting ecosystem productivity in most of the earth's terrestrial biomes (Nemani et al. 2003). Although global precipitation is expected to increase by up to $7 \%$ during the coming decades, global circulation models (GCM) predict divergent patterns at a finer space scale with both increases and decreases in rainfall depending on the geographic area. For the Mediterranean region, GCM forecasts indicate a $20 \%$ decline in mean rainfall during spring and summer (Somot et al. 2008) accompanied by an increased frequency of extreme droughts and heat waves (Sheffield and Wood 2008). Such conditions have already been observed in Europe (Ciais et al. 2005) and, in particular, the Mediterranean region (Schär and Jendritzky 2004). More frequent and intense drought could strongly impact the sustainability of forest ecosystems, by decreasing productivity (Rambal et al. 2003), increasing fire frequency (Mouillot et al. 2002) and promoting forest dieback events (Allen et al.
2010). Despite the potential severity of drought impacts on Mediterranean ecosystems, reliable prediction of forest response to drought remains elusive, owing to limited understanding of water stress effects from the leaf to ecosystem scales (Morales et al. 2005).

Coupled photosynthesis-conductance models represent the fundamental framework of most numerical simulations of growth and productivity performed from stand to regional and even global scales. However, there is a lack of field data to account for the effects of severe drought in model calibrations (Keenan et al. 2010). Although datasets including the drought response of leaf photosynthetic parameters are becoming available for some tree species (Grassi and Magnani 2005; Limousin et al. 2010), most studies are still restricted to individual sites and seasonal time scales. Mechanisms for plant drought response vary with the temporal scale examined (Maseda and Fernandez 2006), so seasonal responses may not be representative of those that will occur in response to climate change. 
At short time scales (i.e. day to season), photosynthesis is limited by stomatal conductance $\left(g_{\mathrm{s}}\right)$, mesophyll conductance and photosynthetic metabolism. Drought-induced stomatal closure is the fastest rate process and is widely recognised as the primary effect of drought on transpiration and carbon assimilation (Chaves 1991; Maseda and Fernandez 2006). Mesophyll conductance $\left(g_{\mathrm{m}}\right)$ from the substomatal cavities to the chloroplast stroma has been shown to be a second, rapidlyresponding diffusive limitation to $\mathrm{CO}_{2}$ assimilation during water stress (Flexas et al. 2008). This limitation has important consequences for the control of water-use efficiency (Warren and Adams 2006) and the accurate modelling of carbon assimilation (Niinemets et al. 2009a). Mesophyll conductance varies with leaf density and thickness, resulting in among-species and within-species differences in adaptive and acclimatory drought response (Niinemets et al. 2009b). Finally, several metabolic impairments can occur when drought is prolonged or intense. Decreased ribulose-1,5-bisphosphate-carboxylase-oxygenase (Rubisco) activity and ribulose-1,5-bisphosphate (RuBP) regeneration capacity have been identified as the most important metabolic impairments (Bota et al. 2004) and may be linked to changes in leaf nitrogen content or allocation (Misson et al. 2006). At seasonal to annual time scales, hydraulic conductance exerts a direct control on leaf gas exchange, by constraining stomatal conductance (Hubbard et al. 2001). At the annual to decadal scale, leaf gas exchange and hydraulic conductance are controlled by growth and carbon partitioning among plant organs. For example, leaf area index (LAI) and root-to-leaf or leaf-to-sapwood ratios commonly acclimate to long-term drought conditions (Zerihun et al. 2006; Limousin et al. 2009). The canopy LAI of a forest is theoretically determined by its water balance, in accordance with the ecohydrological equilibrium concept (Eagleson 1982), which has been shown to apply to Mediterranean evergreen oak woodlands and forests (Hoff and Rambal 2003).

Few studies have examined whether long-term drought acclimation modifies stomatal and non-stomatal limitations to net photosynthesis in response to water stress. Six years of partial throughfall exclusion were found to have no significant impact on the functional relationship between plant water deficit and leaf physiology in a Quercus ilex (L.) forest (Limousin et al. 2010). Here, we asked whether this result holds over a longer time scale. To extend the time span of drought exposure considered in Limousin et al. (2010), we studied drought acclimation in three populations of $Q$. ilex across a natural water availability gradient mediated by topography, assuming that ecosystems will adapt to a changing climate in the same way that they respond to climate variability over space (Rustad 2008). We hypothesised that leaf physiological responses to seasonal water deficit would be conserved across the rainfall gradient, whereas long-term adjustments at the whole-tree scale would compensate for among-site differences in water availability.

\section{Materials and methods}

\section{Study sites}

Three forest plots, dominated by the evergreen Quercus ilex (L.) were selected along a $100-\mathrm{km}$ long WSW-ENE transect in the
French Mediterranean region of Languedoc Roussillon. The three sites have been managed as coppices in the past. We selected stands of comparable age and edaphic characteristics, located across a topographically-induced gradient of mean annual precipitation and air temperature. Specific selection criteria included (1) a closed canopy without major gaps, (2) an evenaged structure, (3) no significant presence of other tree species and (4) similar historical attributes. The last clear cuts of the three coppices occurred between the 1930s and the '50s and no major disturbances have occurred since then. The first and driest stand is located in the Vic la Gardiole State Forest, hereafter referred to as 'dry', with a mean annual temperature of $14.5^{\circ} \mathrm{C}$ and a mean annual precipitation of $650 \mathrm{~mm}$ from 1991 to 2009 (Table 1). The second stand is located within the Puéchabon State Forest. This site has been continuously monitored since 1984 for ecophysiological measurements from the leaf scale (Limousin et al. 2010; Misson et al. 2010a) to stand or ecosystem scales (Rambal et al. 2003; Limousin et al. 2009; Misson et al. 2010b). This site constitutes the 'intermediate' site of the gradient, with a mean annual temperature of $13.4^{\circ} \mathrm{C}$ and a mean annual precipitation of $907 \mathrm{~mm}$ from 1984 to 2009. The 'wet' site is located $70 \mathrm{~km}$ to the north-east of Puéchabon, in Les Mages State Forest, where the mean annual temperature is $12.5^{\circ} \mathrm{C}$ and the mean annual precipitation was $1150 \mathrm{~mm}$ from 1991 to 2009.

Meteorological data for the 'wet' and 'dry' sites were obtained from the La Grand-Combes and Villeneuve Les Maguelones

Table 1. Climate, stand and soil characteristics of the three study sites Climate data represent mean values for 1991-2009. Soil textural characteristics were estimated for the Top $0-30 \mathrm{~cm}$ mean \pm s.e. Abbreviations: $A W C$, available water content within the soil profile; $\mathrm{DBH}$, diameter at breast height; LAI, leaf area index

\begin{tabular}{|c|c|c|c|}
\hline $\begin{array}{l}\text { Site } \\
\text { State forest }\end{array}$ & $\begin{array}{c}\text { 'Dry' } \\
\text { Vic La Gardiole }\end{array}$ & $\begin{array}{l}\text { 'Intermediate' } \\
\text { Puéchabon }\end{array}$ & $\begin{array}{c}\text { 'Wet' } \\
\text { Les Mages }\end{array}$ \\
\hline \multicolumn{4}{|l|}{ Site features } \\
\hline Location & $\begin{array}{c}43^{\circ} 29^{\prime} \mathrm{N} \\
3^{\circ} 45^{\prime} \mathrm{E}\end{array}$ & $\begin{array}{c}43^{\circ} 44^{\prime} \mathrm{N}, \\
3^{\circ} 35^{\prime} \mathrm{E}\end{array}$ & $\begin{array}{c}44^{\circ} 13^{\prime} \mathrm{N} \\
4^{\circ} 8^{\prime} \mathrm{E}\end{array}$ \\
\hline Elevation (m) & 170 & 270 & 360 \\
\hline Annual rainfall (mm) & 650 & 907 & 1150 \\
\hline Mean annual $\mathrm{T}^{\circ}\left({ }^{\circ} \mathrm{C}\right)$ & 14.5 & 13.4 & 12 \\
\hline \multicolumn{4}{|l|}{ Soil texture } \\
\hline Clay $(\%)$ & $52.9 \pm 2.6$ & $44.1 \pm 2.3$ & $31.5 \pm 0.6$ \\
\hline Sand $(\%)$ & $9.8 \pm 0.7$ & $23.9 \pm 0.8$ & $29.8 \pm 0.08$ \\
\hline USDA texture triangle & Silty clay & Clay & Clay loam \\
\hline Coarse fragments $(\%)$ & 70 & 60 & 40 \\
\hline $\mathrm{FC}_{\text {Saxton }} \mathrm{A}^{\mathrm{G}}$ & 0.185 & 0.157 & 0.193 \\
\hline $\mathrm{WP}_{\text {Saxton }} \mathrm{A}$ & 0.124 & 0.099 & 0.106 \\
\hline $\mathrm{AW}_{0-30}{ }^{\mathrm{A}}$ & 18.3 & 17.4 & 26.1 \\
\hline \multicolumn{4}{|l|}{ Tree and stand features } \\
\hline Mean tree age (year) & 64 & 68 & 82 \\
\hline Mean canopy height (m) & 3.15 & 4.15 & 5.8 \\
\hline Top canopy height (m) & 5.5 & 6.5 & 8 \\
\hline Basal area $\left(\mathrm{m}^{2} \mathrm{ha}^{-1}\right)$ & 24 & 34 & 51 \\
\hline LAI $2009 \mathrm{~m}^{2} \mathrm{~m}^{-2}$ & 1.2 & 1.9 & 2.8 \\
\hline No. of stems ha ${ }^{-1}$ & 8578 & 7549 & 5111 \\
\hline
\end{tabular}

${ }^{\mathrm{A}}$ We used pedotransfer functions of Saxton and Rawls (2006). 
weather stations of the Météo France network respectively. Data for the 'intermediate' site of Puéchabon were obtained using a fully equipped weather station, located on site. Variables measured included daily rainfall, as well as daily minimum, maximum and mean temperature. Monthly rainfall and temperature data for the 1991-2009 period were used to characterise the three sites. At each site, we delineated a $15 \times 15 \mathrm{~m}$ plot. The plots were installed in the middle of a wider forest stand of continuous and homogeneous structure, in January 2009. Stand features were measured for each site in January 2010. Stem density and mean diameter at breast height (DBH) were measured on all stems, whereas tree age was assessed through dendrometric measurements on 15 dominant trees per site.

\section{Soil measurements}

Twelve soil samples per site were randomly collected from two depths $(0-10 \mathrm{~cm}$ and $10-20 \mathrm{~cm})$ in December 2009. The presence of shallow bedrock prevented deeper sampling. Below $20 \mathrm{~cm}$, we assumed that the soil filling the fractures in the bedrock had the same characteristics than the soil in the $10-20 \mathrm{~cm}$ horizon. Samples were pooled into groups of three for soil texture analysis. Soil depth above bedrock and stone density were obtained from work by Rambal et al. (2003) for the 'intermediate' site at Puéchabon. In January 2010, the same parameters were measured in three $0.5 \times 0.5 \mathrm{~m}$ soil pits located just outside the plots of both the 'wet' and 'dry' sites.

\section{Leaf area index}

Leaf area index (LAI) was estimated for the measurement year (2009) using leaf litterfall and leaf lifespan data. For the 'intermediate' site, we used 12 litter traps as described by Limousin et al. (2009), covering a total area of $1.1 \mathrm{~m}^{2}$ per plot. At the 'dry' and 'wet' sites, 16 litter traps were installed, covering a total area of $1.3 \mathrm{~m}^{2}$ per plot. Litterfall was collected bi-monthly, beginning in January 2009. Litter was separated into leaves, wood, flowers and acorns, oven dried at $60^{\circ} \mathrm{C}$ then weighed. For each sampling date, the dry mass of leaf litterfall $\left(M_{1 \mathrm{lt}} ; \mathrm{g} \mathrm{m}^{-2}\right)$ was converted to leaf area, by dividing by the leaf mass area of dead leaves $\left(\mathrm{LMA}_{\text {lit }} ; \mathrm{g} \mathrm{m}^{-2}\right)$. Based on long-term observation at the 'intermediate' site, annual leaf litterfall was assumed to be relatively constant for mature stands. We, therefore, used the average value of $\overline{M_{\mathrm{lt}}}$ for 2009 and 2010. Leaf area index was then determined by the formula used by Limousin et al. (2009), as the average annual area of leaves shed, multiplied by the sum of the fractions of surviving leaves in each cohort:

$$
\mathrm{LAI}=\sum_{i=1}^{l l s=3} \frac{\overline{M_{\mathrm{lt}}} \cdot P_{\mathrm{i}}}{\mathrm{LMA}_{\mathrm{lit}}},
$$

where LAI is the leaf area index $\left(\mathrm{m}^{-2} \mathrm{~m}^{-2}\right), l l s$ is the maximum leaf lifespan (3 years) and $P_{\mathrm{i}}$ is the proportion of leaves of each cohort surviving i years. $P_{\mathrm{i}}$ was estimated at each site by counting the leaves and scars of each cohort on six to eight trees per site, including three branches per tree, in February 2009 and 2010. This method of estimating the LAI was validated at the 'intermediate' site against independent measurements performed through optical or allometric methods (S Rambal, unpubl. data).

\section{Leaf water potential and gas exchange measurements}

Predawn and midday leaf water potential $\left(\Psi_{1, \mathrm{pd}}\right.$ and $\left.\Psi_{1, \mathrm{md}}\right)$ were monitored at $\sim 1.5$-month intervals between April and November 2009, using a pressure chamber (PMS 1000, PMS Instruments, Corvallis, OR, USA). Measurements began 1 hour before sunrise and were completed by dawn. Two leaves were sampled on each of six to eight trees per plot. When the observed difference between the two leaves was greater than $0.2 \mathrm{MPa}$, a third leaf was measured. Leaf gas exchange was measured on the same dates and trees as leaf water potential. Measurements were taken on fully illuminated leaves of the youngest mature cohort (i.e. 1 -year-old leaves until current-year leaves were fully developed). Current-year leaves were considered mature on the same measurement date at all sites, so that ontogenetic differences were negligible.

Leaf gas exchange was measured with a portable photosynthesis system (LI-6400, Li-Cor Inc., Lincoln, NE, USA), equipped with a LI-6400-40 Leaf Chamber Fluorometer. Leaves were first acclimated in the chamber for more than $20 \mathrm{~min}$ at a block temperature of $25^{\circ} \mathrm{C}$, ambient $\mathrm{CO}_{2}$ concentration $\left(400 \mu \mathrm{mol} \mathrm{CO} \mathrm{Col}^{-1}\right.$ air) and a saturating photosynthetic photon flux density (PPFD) of $1500 \mu \mathrm{mol} \mathrm{m}^{-2} \mathrm{~s}^{-1}$. Leaf chamber temperature and vapour pressure deficit (VPD) were held as constant as possible among the three sites for a given measurement period. However, over the course of the year, leaf temperature ranged from 18 to $30^{\circ} \mathrm{C}$ and VPD ranged from 1.5 to $4.0 \mathrm{kPa}$, due to seasonal differences in ambient meteorological conditions. Nevertheless, mean cuvette temperature and VPD did not differ among sites $(P>0.1)$. Light-saturated net photosynthesis $\left(A_{\max }\right)$ and stomatal conductance $\left(g_{\mathrm{s}}\right)$ were measured at the end of the 20-min acclimation period. We then measured the photosynthetic response to substomatal $\mathrm{CO}_{2}$ concentration $\left(A-C_{i}\right.$ curve), by modifying the $\mathrm{CO}_{2}$ concentration according to the following sequence: $200,100,50,300,500,700,1000,1400$ and $1900 \mu \mathrm{mol} \mathrm{CO} \mathrm{mol}^{-1}$. Leaves were allowed to equilibrate for at least $3 \mathrm{~min}$ at each step before logging data. After the completion of the $A-C_{\mathrm{i}}$ curve, the light was switched off and leaf respiration rate was measured after $3 \mathrm{~min}$ at the ambient $\mathrm{CO}_{2}$ concentration. Net photosynthesis and $C_{\mathrm{i}}$ values at each step were corrected for $\mathrm{CO}_{2}$ diffusion leaks, following the manufacturer's recommendation and using a diffusion correction term $(k)$ of $0.46 \mu \mathrm{mol} \mathrm{s}^{-1}$ (Li-Cor Inc.).

At each of the nine steps of the $A-C_{i}$ curve, the photochemical efficiency of PSII $\left(\Phi_{\mathrm{PSII}}\right)$ was determined as $\Phi_{\mathrm{PSII}}=\left(F_{\mathrm{m}}{ }^{\prime}-F_{\mathrm{s}}\right) /$ $F_{\mathrm{m}}{ }^{\prime}$, by measuring steady-state fluorescence $\left(F_{\mathrm{s}}\right)$ and maximum fluorescence $\left(F_{\mathrm{m}}{ }^{\prime}\right)$ during a light-saturating pulse. The rate of photosynthetic electron transport $\left(J_{\mathrm{ETR}}\right)$ was then calculated following Krall and Edwards (1992), as $J_{\mathrm{ETR}}=0.5 \Phi_{\mathrm{PSII}}$. $\alpha$ PPFD, where 0.5 is a factor accounting for the distribution of light between the two photosystems and $\alpha$ is leaf absorptance, which was estimated at 0.93 , based on previous work in $Q$. ilex leaves (Niinemets et al. 2005). The relationship between $\Phi_{\mathrm{PSII}}$ and $J_{\text {ETR }}$ was not calibrated in this study, but has previously been shown to be valid for $Q$. ilex leaves (Niinemets et al. 2006). Furthermore, any error in the $J_{\mathrm{ETR}}$ estimate would be systematic among sites. Leaf chlorophyll content was assessed with a SPAD chlorophyll meter (SPAD-502, Konica Minolta Sensing Co., 
Osaka, Japan). Changes in leaf absorbance with water stress were assumed to be negligible, because SPAD remained near 46 throughout the measurement period with no differences among sites $(P=0.4)$.

\section{Mesophyll conductance and $\mathrm{A}-\mathrm{C}_{C}$ based photosynthetic parameters}

The internal mesophyll diffusion conductance from the substomatal chamber to the chloroplasts $\left(g_{\mathrm{m}}\right)$ was estimated following the variable electron transport rate method by Harley et al. (1992b):

$$
g_{\mathrm{m}}=\frac{A}{C_{\mathrm{i}}-\frac{\Gamma^{*}\left[J_{\mathrm{ETR}}+8\left(A+R_{\mathrm{d}}\right)\right]}{J_{\mathrm{ETR}}-4\left(A+R_{\mathrm{d}}\right)},}
$$

The $\mathrm{CO}_{2}$ compensation point in the absence of mitochondrial respiration $\left(\Gamma^{*}\right)$ was taken from (Bernacchi et al. 2002), and the rate of non-photorespiratory respiration continuing in the light $\left(R_{\mathrm{d}}\right)$ was taken as half of the rate of respiration measured in the dark (Niinemets et al. 2005). Mesophyll conductance was calculated for every step of the $A-C_{\mathrm{i}}$ curves, and then used to convert them to $A-C_{\mathrm{c}}$ curves, with $C_{\mathrm{c}}$ being the $\mathrm{CO}_{2}$ concentration in the chloroplast stroma:

$$
C_{\mathrm{c}}=C_{\mathrm{i}}-A / g_{\mathrm{m}},
$$

This method accounts for the variation of $g_{\mathrm{m}}$ with $C_{\mathrm{i}}$, and provides more accurate estimates of photosynthetic parameters than $A-C_{\mathrm{c}}$ curves that assume a constant $g_{\mathrm{m}}$, especially during episodes of water stress (Flexas et al. 2007). $A-C_{\mathrm{c}}$ curves were used to estimate maximum carboxylation $\left(V_{\mathrm{cmax}}\right)$ and electron transport $\left(J_{\max }\right)$ rates, by fitting the equations of the Farquhar et al. (1980) model. The Michaelis-Menten constants for carboxylation $\left(K_{\mathrm{c}}\right)$ and oxygenation $\left(K_{\mathrm{o}}\right)$ for $A-C_{\mathrm{c}}$ curve fitting were taken from Bernacchi et al. (2001).

We caution that calculations of $g_{\mathrm{m}}$ and, consequently, $V_{\text {cmax }}$ and $J_{\max }$, may be biased if non-uniform stomatal closure affects $C_{\mathrm{i}}$ estimation (Beyschlag et al. 1992). However, non-uniform stomatal closure is generally negligible before $g_{\text {s }}$ reaches very low values (Buckley et al. 1997). Given that $g_{\mathrm{m}}$ decreased in parallel with $g_{\mathrm{s}}$ in the present study and the sensitivity of $g_{\mathrm{m}}$ to $C_{\mathrm{i}}$ is low under these conditions (Buckley et al. 1997), $g_{\mathrm{m}}, V_{\mathrm{cmax}}$ and $J_{\max }$ estimations were deemed to be valid. The Harley et al. (1992a) formulation was used to normalise $V_{\text {cmax }}$ and $J_{\max }$ to the reference temperature of $25^{\circ} \mathrm{C}$, according to existing calibrations for $Q$. ilex (Limousin et al. 2010). Mesophyll conductance estimates were normalised to $25^{\circ} \mathrm{C}$ using the Bernacchi et al. (2002) formulation.

\section{Leaf chemical and structural parameters}

The whole leaves sampled for gas-exchange measurements were collected for chemical and structural analysis. Leaf area was determined with an optical area meter (Delta-T devices Ltd, Cambridge, UK). The leaves were then oven-dried at $60^{\circ} \mathrm{C}$ for at least $48 \mathrm{~h}$, and weighed for their dry mass. Leaf nitrogen content per dry mass $\left(N_{\mathrm{M}}\right)$ was measured using an elemental analyser (Flash EA1112 Series, ThermoFinnigan, Milan, Italy). The apparent nitrogen fraction in Rubisco $\left(P_{\mathrm{R}}\right)$ and in the rate- limiting proteins of photosynthetic electron transport $\left(P_{\mathrm{B}}\right)$ were then determined following Niinemets and Tenhunen (1997):

$$
\begin{aligned}
P_{\mathrm{R}} & =\frac{V_{\mathrm{cmax}}}{6.25 \cdot V_{\mathrm{cr}} \cdot N_{\mathrm{M}} \cdot \mathrm{LMA}}, \\
P_{\mathrm{B}} & =\frac{J_{\mathrm{max}}}{8.06 \cdot J_{\mathrm{me}} \cdot N_{\mathrm{M}} \cdot \mathrm{LMA}},
\end{aligned}
$$

where $V_{\text {cr }}$ is the maximum rate of ribulose-1,5-bisphosphate carboxylation per unit Rubisco protein $\left(V_{\mathrm{cr}}=20.5 \mu \mathrm{mol}\right.$ $\mathrm{CO}_{2}$ (g Rubisco) $)^{-1} \mathrm{~s}^{-1}$ at $25^{\circ} \mathrm{C}$ ), $J_{\mathrm{mc}}$ is the capacity for photosynthetic electron transport per unit cytochrome $\mathrm{f}$ $\left(J_{\mathrm{mc}}=156 \mathrm{~mol} \mathrm{e} \mathrm{e}^{-}(\mathrm{molcyt})^{-1} \mathrm{~s}^{-1}\right.$ at $\left.25^{\circ} \mathrm{C}\right)$, and the scaling coefficients, 6.25 and 8.06, are based on the stoichiometry of the nitrogen content of proteins and rate-limiting proteins respectively (Niinemets and Tenhunen 1997).

\section{Quantitative limitation analysis}

The relative limitations to photosynthesis imposed by stomatal conductance $\left(S_{\mathrm{L}}\right)$, mesophyll conductance $\left(M C_{\mathrm{L}}\right)$ and biochemical processes $\left(B_{\mathrm{L}}\right)$ were partitioned following the approach proposed by Grassi and Magnani (2005) and previously applied to $Q$. ilex by Limousin et al. (2010). Using measurements of $A_{\max }, g_{\mathrm{s}}, g_{\mathrm{m}}$ and $V_{\text {cmax }}$, limitations to photosynthesis were expressed as proportions of the maximum rates measured under unstressed conditions. Since light is saturating, $A_{\max }$ is considered to be limited by substrate availability, in accordance with the Farquhar et al. (1980) model. Changes in $A_{\max }$ can then be expressed in terms of concomitant changes in $V_{\mathrm{cmax}}$ and $C_{\mathrm{c}}$, the latter itself a function of changes in $g_{\mathrm{s}}, g_{\mathrm{m}}$ and $A_{\max } . S_{\mathrm{L}}, M C_{\mathrm{L}}$ and $B_{\mathrm{L}}$ were calculated from the proportional declines in $g_{\mathrm{s}}, g_{\mathrm{m}}$ and $V_{\mathrm{cmax}}$, respectively, relative to the highest values measured during the study period.

\section{Statistical analyses}

In this study, we performed measurements on trees growing at different sites and experiencing different meteorological conditions over the sampling period. Among-site differences in gas-exchange rates and photosynthetic limitations could, therefore, be confounded by varying degrees of water stress observed on the measurement dates at each site. To distinguish between intrinsic differences in drought sensitivity and transient water stress effects, we measured our variables of interest across a wide range of $\Psi_{1, p d}$, which was used as a surrogate for water stress intensity. For each tree, the following nonlinear model (selected for its good representation of the data with only two parameters) was used to describe the relationship between leaf water potential and each physiological variable of interest $(\varphi)$ :

$$
\varphi=a \times \exp \left(b \times \Psi_{1, \mathrm{pd}}\right),
$$

where $a$ and $b$ are fitted parameters describing the slope and scaling exponents respectively. Maximum leaf physiological parameters measured in the absence of water stress did not differ among sites $\left(P>0.1\right.$ for $\Psi_{1, \mathrm{pd}}>-0.7$, ANOVA), so we restricted our analysis to the comparison of scaling exponents. When the fitted scaling exponents were normally distributed (Shapiro-Wilk test, $P>0.4$ ), site differences were tested using 
ANOVA, with trees considered as replicates. The scaling exponents for electron transport rate $\left(J_{\max }\right)$ and mesophyll conductance $\left(g_{m}\right)$ did not exhibit a normal distribution at the 'wet' site $(P<0.05)$. A $\log$ transformation was applied to the exponent values for these two variables at all sites before ANOVA testing. Site effects were considered significant below a threshold $P$-value of 0.05 . Pair-wise Student's $t$-tests were used to discriminate specific among-site differences when the ANOVA revealed a site effect. Stomatal conductance $\left(g_{\mathrm{s}}\right)$ can also be used as an integrated indicator of plant response to water stress (Medrano et al. 2002), so we also expressed the photosynthetic variables $\left(A_{\max }, V_{\mathrm{cmax}}, J_{\max }, g_{\mathrm{m}}\right)$ as a function of $g_{\mathrm{s}}$ and tested for a site effect, a $g_{\mathrm{s}}$ effect, and the interaction between $g_{\mathrm{s}}$ and site, using analysis of covariance (ANCOVA). ANCOVA was also used to explore the effect of site and $\Psi_{1, \text { pd }}$ on minimum leaf water potential $\left(\Psi_{1, \mathrm{md}}\right)$. Two-way analyses of variance were used to test for differences in leaf traits (LMA, N) and photosynthetic variables among sites and measurement dates, as well as to test for site $\times$ date interactions in these variables.

\section{Results}

\section{Site and stand features}

The three study sites are located across a strong rainfall gradient. At the 'wet' site of Les Mages, mean annual rainfall is $77 \%$ higher and mean annual temperature is $2.5^{\circ} \mathrm{C}$ lower than at the 'dry' site of Vic La Gardiole, primarily due to its higher elevation (Table 1).

Among sites, we found an opposite gradient of soil texture and percentage of coarse fragments (Table 1). The soil of the 'dry' site was a silty-clay (US Department of Agriculture, texture triangle, http://soils.usda.gov/technical/aids/investigations/ texture/) and had a high stone content whereas the soil of the 'wet' site was a clay-loam but was deeper and had a lower stone content. The 'intermediate' site had a clay soil and presented intermediate stone contents compared with both other (Table 1). Consequently, the 'dry' and the 'intermediate' site had similar ability to retain water whereas the 'wet' site higher available water content (Table 1). In response to the water availability gradient stand basal area (BA) and leaf area index (LAI) increased across the wetness gradient, with values of LAI $1.2,1.9$, and $2.8 \mathrm{~m}^{2} \mathrm{~m}^{-2}$ and values of BA of 24,34 and $51 \mathrm{~m}^{2} \mathrm{ha}^{-1}$ for the 'dry', 'intermediate' and 'wet' sites respectively.

\section{Water stress}

A strong precipitation gradient was observed in 2009, which was a drier than normal year, with annual rainfall of 459, 747 and $871 \mathrm{~mm}$ at the 'dry', 'intermediate' and 'wet' sites respectively (Fig. 1a-c). Predawn leaf water potential $\left(\Psi_{1, \mathrm{pd}}\right)$ began to decrease at the beginning of June at all sites, falling below -1 MPa by mid-July. Trees at the 'wet' site experienced the shortest and least intense drought with a minimum $\Psi_{1, \text { pd }}$ value of $-2.2 \mathrm{MPa}$ in July and an early recovery after rainfall in late August (day of year (DOY) 240). Trees at the 'intermediate' site recovered from water stress after several rainfall events in midSeptember. The 'dry' site experienced the longest drought, although average $\Psi_{1, p d}$ values did not fall below the minimum value of $-3.2 \mathrm{MPa}$ reached at the 'intermediate' site (Fig. 1b). A
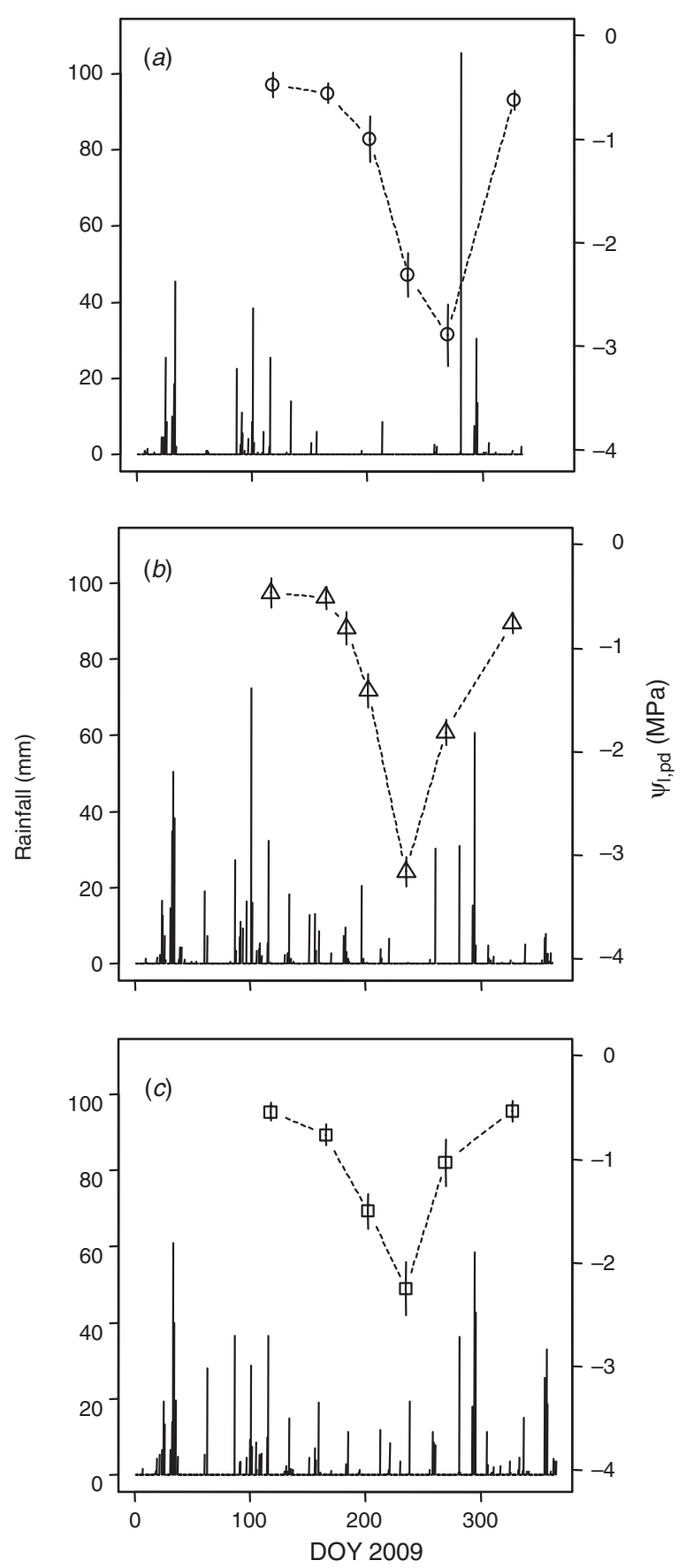

Fig. 1. Mean predawn leaf water potential in 2009. Points show the mean leaf water potential of six to eight trees per site and measurement date ( \pm s.e.). Bar plots show daily rainfall. Note: 'a', 'b' and 'c' refer to the 'dry', 'intermediate' and 'wet' sites respectively.

$105 \mathrm{~mm}$ rainfall event in October (DOY 280) facilitated $\Psi_{1, \mathrm{pd}}$ recovery to pre-drought conditions at the 'dry' site. Midday leaf water potential $\left(\Psi_{1, \mathrm{md}}\right)$ was positively and linearly correlated with predawn leaf water potential $\left(\Psi_{1, p d}\right)$ at all sites (Fig. 2). The slopes of the $\Psi_{1, \mathrm{md}} \mathrm{Vs} \Psi_{1, \mathrm{pd}}$ regression lines did not differ among the three sites (ANCOVA, $P=0.225$ ). 


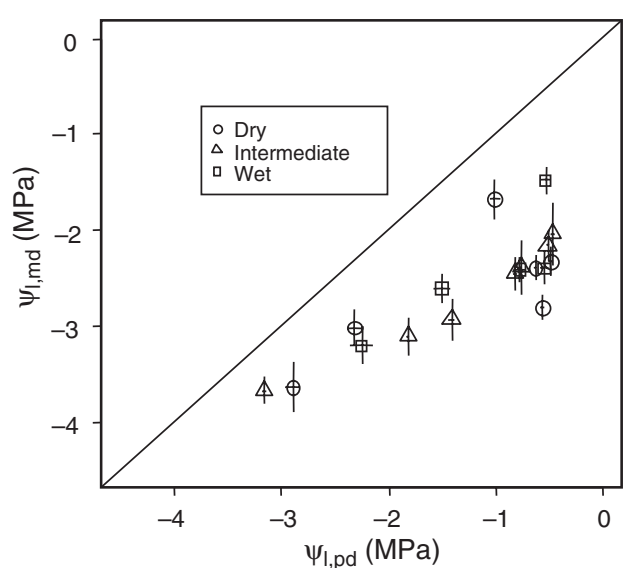

Fig. 2. Relationships between midday leaf water potential $\left(\Psi_{1, \mathrm{md}}\right)$ and predawn leaf water potential $\left(\Psi_{1, \mathrm{pd}}\right)$. Data points show the mean values for each date $( \pm$ s.e.). Circles represent data from the 'dry' site; triangles and squares are used for the 'intermediate' and 'wet' sites respectively. Analysis of covariance revealed neither site effects $(P=0.56)$ nor site $\times \Psi_{1, \mathrm{pd}}$ interaction $(P=0.47)$. Estimates of the fitted linear regression for the whole dataset are $-1.91 \mathrm{MPa}$ (intercept) and 0.60 (slope; $R^{2}=0.62$ ). A $1: 1$ line is shown.

\section{Leaf physiological parameters}

Maximum values of light-saturated photosynthesis $\left(A_{\max }\right)$ and stomatal conductance $\left(g_{\mathrm{s}}\right)$ were similar among sites in the absence of water stress ( $\Psi_{1, \mathrm{pd}}>-0.7 \mathrm{MPa}$; Table 2$)$, but decreased strongly in response to lower $\Psi_{1, \text { pd }}$. Minimum values of $g_{s}$ were similar at all three sites of the rainfall gradient (near $20 \mathrm{mmol} \mathrm{m}^{-2} \mathrm{~s}^{-1}$ ), whereas $A_{\max }$ reached slightly lower values at the 'wet' site. However, these minima were reached at higher $\Psi_{1, \mathrm{pd}}(-2.2 \mathrm{MPa})$ at the 'wet' site than at the 'intermediate' and 'dry' sites (near $-3.2 \mathrm{MPa}$ ). Consequently, the fitted scaling exponents of the relationship between $\Psi_{1, \mathrm{pd}}$ and either $A_{\max }$ or $g_{s}$ were similar for the 'dry' and 'intermediate' sites, but $A_{\max }$ and $g_{s}$ declined more steeply in response to declining $\Psi_{1, \mathrm{pd}}$ at the 'wet' site (Fig. $3 a, b$; Table 3). Maximum carboxylation capacity $\left(V_{\text {cmax }}\right)$, photosynthetic electron transport rate $\left(J_{\max }\right)$ and mesophyll conductance $\left(g_{\mathrm{m}}\right)$ also showed similar maximum values among sites at high $\Psi_{1, p d}$ (Table 2), but decreased strongly with increasing water stress. As observed for $A_{\max }$ and $g_{\mathrm{s}}$, maximum carboxylation capacity, $J_{\max }$ and $g_{\mathrm{m}}$ were more sensitive to low $\Psi_{1, \mathrm{pd}}$ at the 'wet' site (Fig. $3 e, f$ ), so that the scaling exponents relating these variables to $\Psi_{1, p d}$ were higher than at the other two sites (Student's $t$-tests, $P<0.05$ for all

Table 2. Mean values and standard deviations of LMA and leaf nitrogen (N) for the overall dataset (i.e. pooled data for all sites) and for each site. Leaf $\mathrm{N}$ content is expressed both per unit dry matter $(\mathrm{N}, \%)$ and per unit area $\left(\mathrm{N}, \mathrm{g} \mathrm{m}^{-2}\right)$

Values of leaf photosynthetic parameters for each site under unstressed conditions $\left(\Psi_{1, \mathrm{pd}}>-0.7 \mathrm{MPa}\right)$ are also shown (s.d.). For both LMA and leaf N, $P$ are provided for two-way analyses of variance (ANOVA; site, date and site $\times$ date interaction). For leaf photosynthetic parameters, $P$ are provided for two way analysis of variance, including the effect of site, Date during unstressed conditions (the first date of measurements before summer drought and the last date of measurements after summer drought, B - A) and their interactions

\begin{tabular}{|c|c|c|c|c|c|c|}
\hline & Overall & 'Dry' & Control & 'Wet' & Parameter & $\bar{P}$ \\
\hline \multicolumn{7}{|c|}{ Leaf structural parameters } \\
\hline \multirow[t]{3}{*}{ LMA } & $225.56(25.18)$ & $221.34(27.56)$ & $231.56(25.41)$ & $224.76(30.65)$ & Site & 0.21 \\
\hline & & & & & Date & 0.42 \\
\hline & & & & & Site $\times$ date & 0.91 \\
\hline \multirow[t]{3}{*}{$\mathrm{N} \%$} & $1.29(0.16)$ & $1.29(0.15)$ & $1.27(0.13)$ & $1.31(0.27)$ & Site & 0.53 \\
\hline & & & & & Date & 0.10 \\
\hline & & & & & Site $\times$ date & 0.49 \\
\hline \multirow[t]{3}{*}{$\mathrm{N}\left(\mathrm{g} / \mathrm{m}^{2}\right)$} & $2.90(0.43)$ & $2.85(0.43)$ & $2.94(0.37)$ & $2.92(0.46)$ & Site & 0.58 \\
\hline & & & & & Date & 0.48 \\
\hline & & & & & Site $\times$ date & 0.20 \\
\hline \multicolumn{7}{|c|}{ Unstress leaf photosynthetic parameters (12-16 per plot) } \\
\hline \multirow[t]{3}{*}{$g_{\mathrm{s}}$} & $88(0.035)$ & $91(0.034)$ & $85(0.035)$ & $86(0.036)$ & Site & 0.67 \\
\hline & & & & & Date & 0.46 \\
\hline & & & & & Site $\times$ date & 0.70 \\
\hline \multirow[t]{3}{*}{$A_{\mathrm{m}}$} & $9.62(3.72)$ & $9.04(3.87)$ & $8.80(3.38)$ & $8.72(4.05)$ & Site & 0.92 \\
\hline & & & & & Date & 0.41 \\
\hline & & & & & Site $\times$ date & 0.62 \\
\hline \multirow[t]{3}{*}{$g_{\mathrm{m}}$} & $130(0.07)$ & $124(0.07)$ & $131(0.07)$ & $123(60)$ & Site & 0.53 \\
\hline & & & & & Date & 0.82 \\
\hline & & & & & Site $\times$ date & 0.34 \\
\hline \multirow[t]{3}{*}{$V_{\text {cmax }}$} & $86(33)$ & $79(32)$ & $87(40)$ & $91(27.5)$ & Site & 0.49 \\
\hline & & & & & Date & 0.88 \\
\hline & & & & & Site $\times$ date & 0.45 \\
\hline \multirow[t]{3}{*}{$J_{\max }$} & $139(44)$ & $132(49)$ & $139(36)$ & 147 (44) & Site & 0.65 \\
\hline & & & & & Date & 0.47 \\
\hline & & & & & Site $\times$ date & 0.85 \\
\hline
\end{tabular}



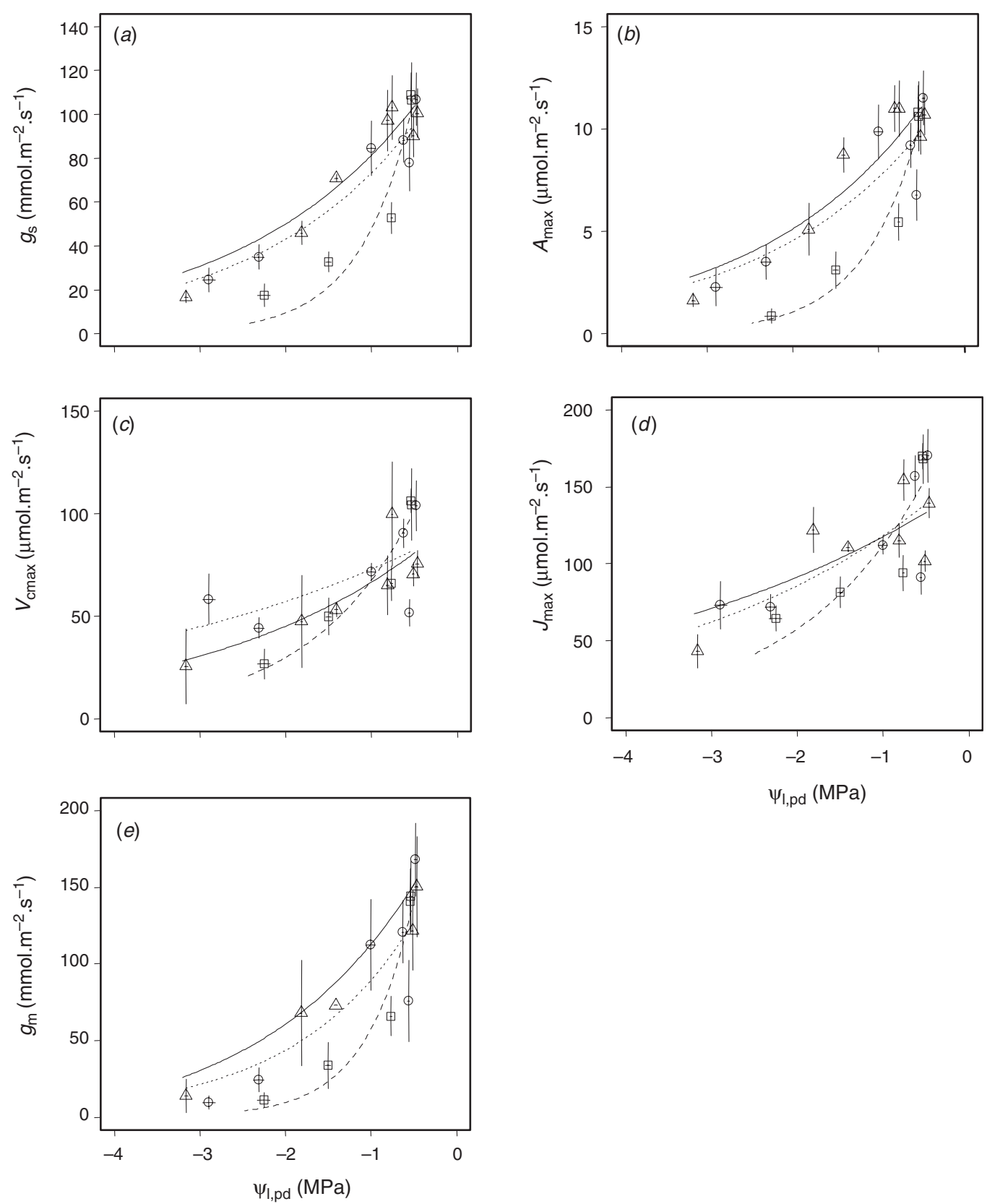

Fig. 3. Relationships between predawn leaf water potential and leaf gas exchange. Data points indicate the mean values for each date $( \pm$ s.e. $)$ for $(a)$ stomatal conductance $\left(g_{\mathrm{s}}\right),(b)$ light saturated assimilation $\left(A_{\max }\right),(c)$ maximum Rubisco carboxylation rate $\left(V_{\text {cmax }}\right),(d)$ maximum rate of photosynthetic electron transport $\left(J_{\max }\right)$ and $(e)$ mesophyll conductance $\left(g_{\mathrm{m}}\right)$. Circles indicate data from the 'dry' site; triangles and squares are used for the 'intermediate' and 'wet' sites respectively. Non-linear regression lines fitted to the data are provided for each site and variable, with plain lines used for the 'dry' site and dotted and dashed lines used for the 'intermediate' and 'wet' sites respectively.

variables except for $V_{\text {cmax }}$ between the 'wet' and 'intermediate' sites $(P=0.065)$; Table 3$)$. No significant interaction between site and $g_{\mathrm{s}}$ were revealed by the ANCOVA with $g_{\mathrm{s}}$ used as the explanatory variable for $A_{\max }, V_{\text {cmax }}, J_{\max }$ or $g_{\mathrm{m}}(P>0.1$; Table 4$)$. Thus, intrinsic differences between sites disappeared when photosynthetic parameters were expressed as a function of $g_{\mathrm{s}}$ instead of as a function of $\Psi_{1, \text { pd }}$ (Fig. 4).

\section{Leaf nitrogen content and investment in photosynthesis}

Leaf mass per unit area (LMA) was similar at the three sites (Table 2). Only mature leaves were sampled, so LMA remained constant throughout the study period, without any notable effect of seasonality or drought (Table 2). Leaf nitrogen content did not show any significant change among sites or measurement dates on 


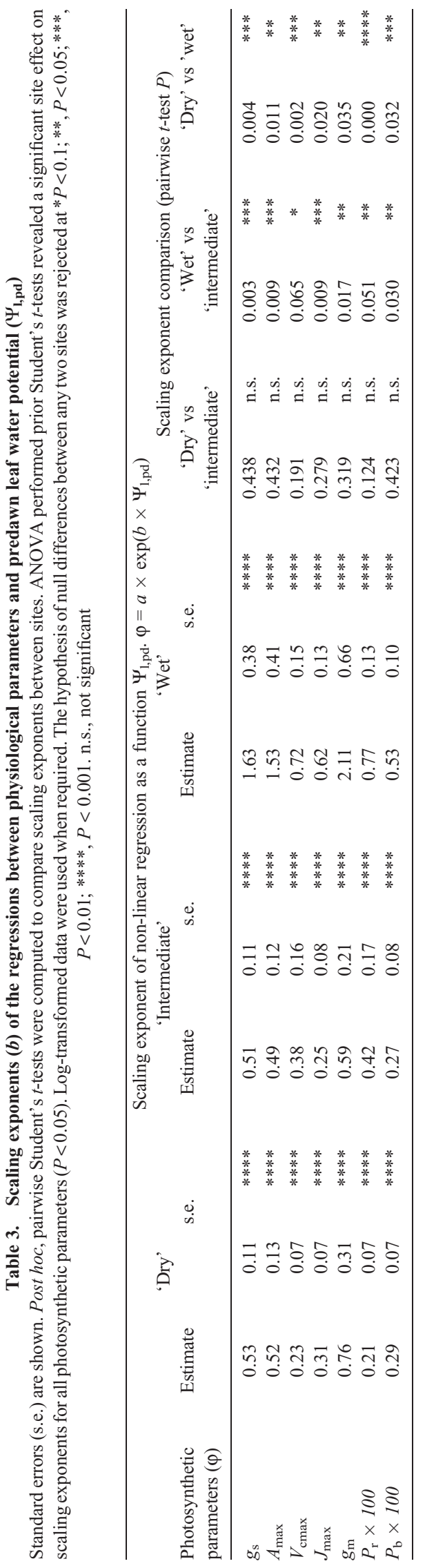

either a mass or leaf-area basis (Table 2). By contrast, apparent investment of nitrogen in Rubisco $\left(P_{\mathrm{R}}\right)$ and in proteins limiting photosynthetic electron transport $\left(P_{\mathrm{B}}\right)$ strongly decreased in response to water stress at all sites, exhibiting fitted scaling exponents similar to those for $V_{\text {cmax }}$ and $J_{\max }$ (Table 3). Thus, the reduction of $P_{\mathrm{R}}$ and $P_{\mathrm{B}}$ with decreasing $\Psi_{1, \mathrm{pd}}$ occurred faster at the 'wet' site than at the 'dry' and 'intermediate' sites (Table 3, $\mathrm{P}<0.05$ for both sites).

\section{Quantitative limitation analysis}

The relationships between $\Psi_{1, p d}$ and the stomatal and nonstomatal photosynthetic limitations are shown in Fig. 5. At the 'dry' and the 'intermediate' sites, total photosynthetic limitation $\left(T_{\mathrm{L}}\right)$ reached maximum values of $0.80-0.85$ at similar $\Psi_{1, p d}(-3$ and $-3.2 \mathrm{MPa}$ respectively). In contrast, $T_{\mathrm{L}}$ reached a maximum value of 0.92 under less stressful conditions $\left(\Psi_{1, p d}=-2.2 \mathrm{MPa}\right)$ at the 'wet' site. Overall, stomatal $\left(S_{\mathrm{L}}\right)$, mesophyll $\left(M C_{\mathrm{L}}\right)$, biochemical $\left(B_{\mathrm{L}}\right)$, total $\left(T_{\mathrm{L}}=S_{\mathrm{L}}+M_{\mathrm{L}}+B_{\mathrm{L}}\right)$ and non-stomatal $\left(N S_{\mathrm{L}}=M C_{\mathrm{L}}+B_{\mathrm{L}}\right)$ limitations were stronger at the 'wet' site than at the two other sites for a given value of $\Psi_{1, p d}$ (Fig. 5). The ranking of limitations $\left(S_{\mathrm{L}}>M_{\mathrm{L}}>B_{\mathrm{L}}\right)$ was conserved among sites.

\section{Discussion}

There is a pressing need for extensive field studies of tree ecophysiology in order to elucidate the impacts of ongoing and future climate changes on Mediterranean forests. Ecosystem manipulation experiments are particularly useful, as these enable more rigorous control of the environmental factors that will be encountered in future climates. However, a major drawback of ecosystem manipulations is that controls on the environmental conditions eliciting plant physiological responses to stress tend to be limited in space and time, due to cost, labour and other logistical considerations (Dunne et al. 2004; Leuzinger et al. 2011). In the present study, we examined the effect of seasonal drought on leaf photosynthetic traits in three populations of $Q$. ilex located along a regional gradient of rainfall. We found that maximum values of leaf photosynthetic parameters, as well as maximum limitations to photosynthesis, were similar in the three populations. However, sensitivity to decreasing $\Psi_{1, p d}$ was higher in trees from the wettest site than in those from the driest (southern) site. Although there are a variety of possible explanations for this observation, our results collectively suggest that adaptive and acclimatory differences in whole-tree hydraulic architecture may explain the divergence of drought sensitivity across the rainfall gradient.

\section{Between-site differences in leaf traits}

Long-term exposure to differences in the frequency, duration and severity of drought did not affect the leaf photosynthetic capacities or gas-exchange rates observed in the absence of water stress, either before or after summer drought (Table 2). This result is consistent with the fact that leaf nitrogen content $(\mathrm{N})$ and leaf mass per unit area (LMA), which are the main drivers of leaf photosynthetic capacity (Niinemets and Tenhunen 1997), remained constant among sites (Table 2). The effect of drought on LMA is generally limited in drought resistant species (Poorter et al. 2009). For $Q$. ilex, a significant trend of increasing LMA 
Table 4. Analysis of covariance of photosynthetic parameters vs $\boldsymbol{g}_{\mathrm{s}}$, site and their interaction $P>0.1$, not significant, $* P<0.1 ; * *, P<0.05 ; * * *, P<0.01 ; * * * *, P<0.001$

\begin{tabular}{|c|c|c|c|c|c|c|c|c|}
\hline \multirow[b]{2}{*}{ Effect } & \multicolumn{2}{|c|}{$A_{\max }$} & \multicolumn{2}{|c|}{$V_{\text {cmax }}$} & \multicolumn{2}{|c|}{$J_{\max }$} & \multicolumn{2}{|c|}{$g_{\mathrm{m}}$} \\
\hline & F value & $P$ & $F$ value & $P$ & F value & $P$ & $\mathrm{~F}$ value & $P$ \\
\hline$g_{\mathrm{s}}$ & 860.95 & $<2 \mathrm{e}-16^{* * * *}$ & 139.16 & $<2 \mathrm{e}-16^{* * * *}$ & 228.41 & $<2 \mathrm{e}-16^{* * * *}$ & 154.32 & $<2 \mathrm{e}-16^{* * * * *}$ \\
\hline$g_{\mathrm{s}} \times$ site & 0.23 & 0.79 & 1.38 & 0.25 & 1.86 & 0.16 & 1.15 & 0.32 \\
\hline
\end{tabular}
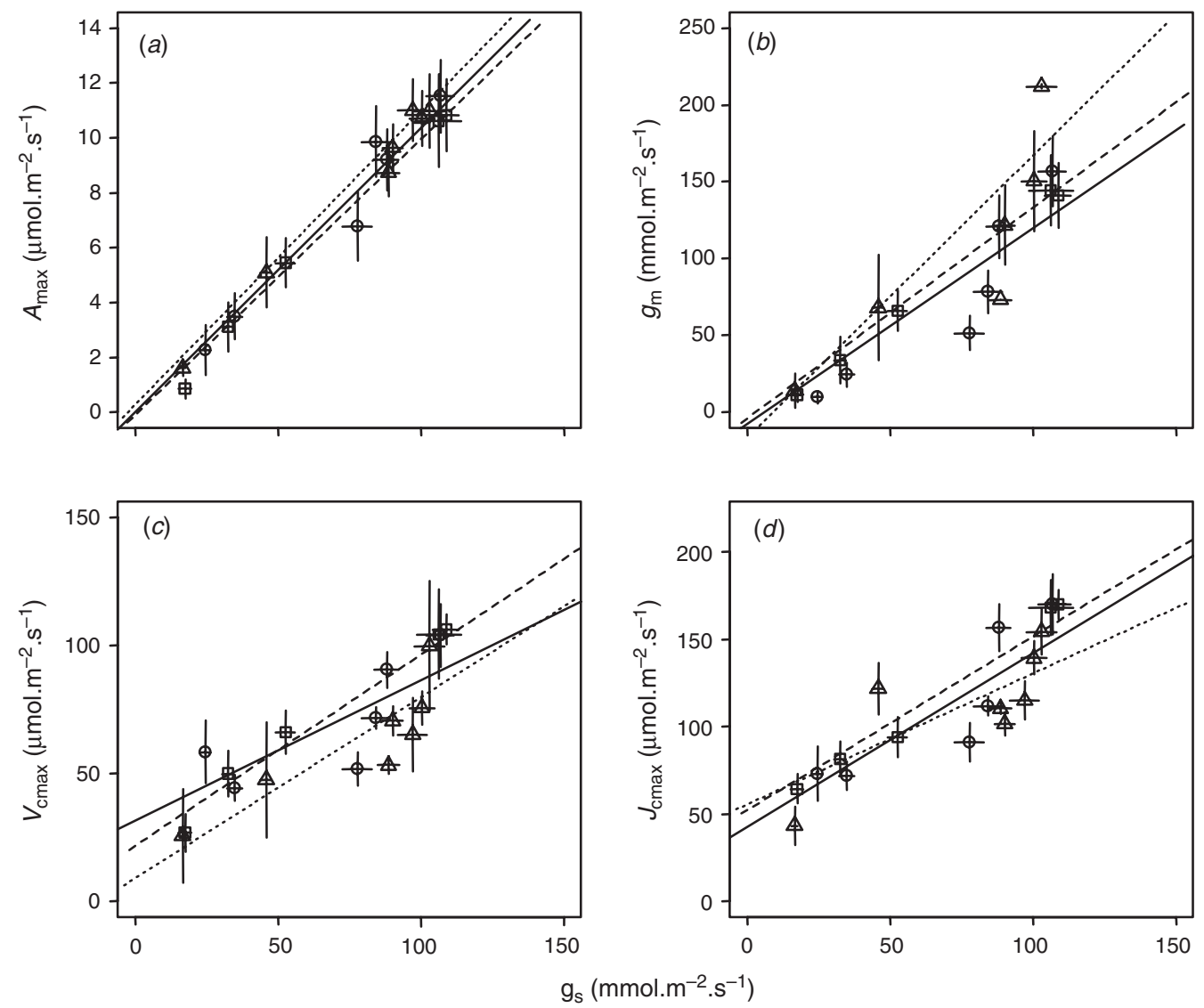

Fig. 4. Leaf photosynthetic variables $\left(A_{\max }, V_{\mathrm{cmax}}, J_{\max }, g_{\mathrm{m}}\right)$, expressed as a function of stomatal conductance $\left(g_{\mathrm{s}}\right)$. Circles indicate data from the 'dry' site; triangles and squares are used for the 'intermediate' and 'wet' sites respectively. Linear regression lines are provided for each site and variable, with plain lines used for the 'dry' site and dotted and dashed lines used for the 'intermediate' and 'wet' sites respectively.

with decreasing rainfall has been observed along a rainfall gradient in Spain (Castro-Diez et al. 1997), but LMA is more strongly driven by cold temperature than by water scarcity (Ogaya and Penuelas 2007). In our study, this temperature effect may have mitigated the response of LMA to changes in water availability.

Maximum biochemical $\left(B_{\mathrm{L}}\right)$ and diffusive $\left(M C_{\mathrm{L}}, S_{\mathrm{L}}\right)$ limitations to photosynthesis were of the same order of magnitude at all sites. Mean values of total $\left(T_{\mathrm{L}}\right)$, stomatal $\left(S_{\mathrm{L}}\right)$, mesophyll $\left(M C_{\mathrm{L}}\right)$ and biochemical $\left(B_{\mathrm{L}}\right)$ limitations reached 87 , 40,30 and $17 \%$ respectively, in agreement with previously published results for this species under similar water stress intensity (Limousin et al. 2010) and more generally for other tree species (Grassi and Magnani 2005). The rank order of these limitations was conserved among sites, regardless of predawn leaf water potential (Fig. 5). However, the $b$ parameter that defines the scaling exponents fitted between physiological parameters and $\Psi_{1, p d}$ was significantly higher at the "wet' site (Table 3), which led to steeper increases in all photosynthetic limitations with increasing seasonal drought (Fig. 3).

The drought sensitivities of stomatal conductance $\left(g_{\mathrm{s}}\right)$, mesophyll conductance $\left(g_{\mathrm{m}}\right)$ and metabolic processes driving leaf photosynthesis have been extensively studied. Leaf physiological parameters are usually expressed as a function of leaf relative water content or predawn leaf water potential (see Lawlor and Cornic 2002 for a review) and relationships are mostly conserved within species (Tardieu and Simonneau 1998). Here, we examined the difference in drought sensitivity among sites, by 

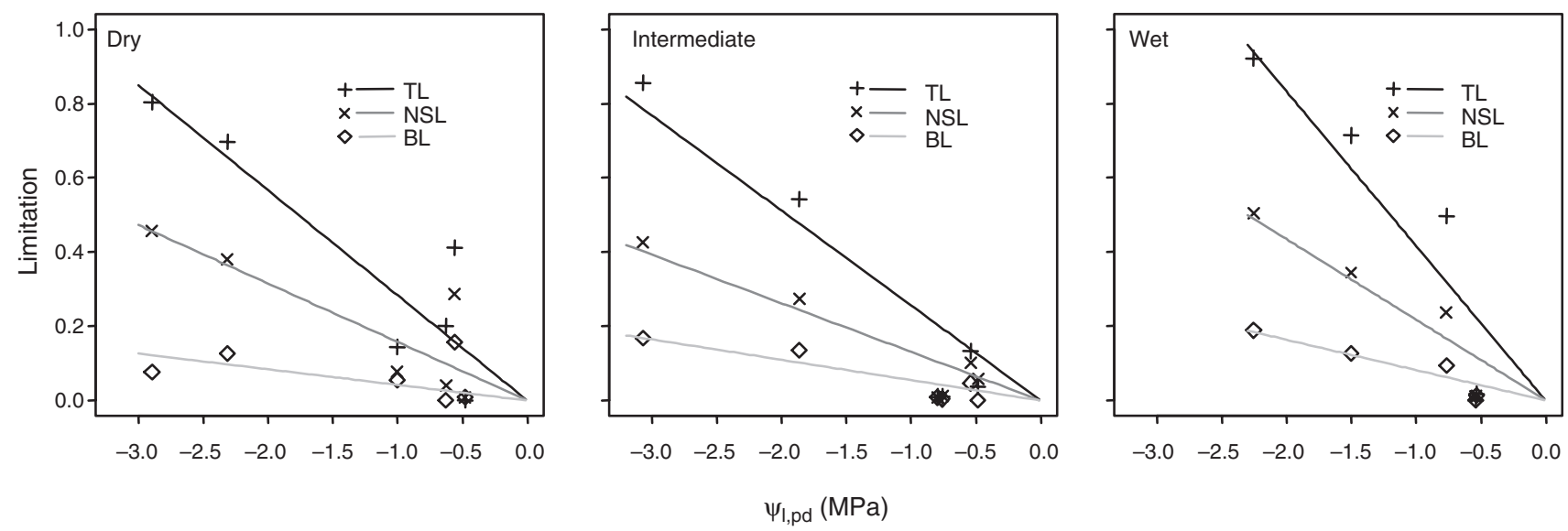

Fig. 5. Biochemical $\left(B_{\mathrm{L}}\right)$, non-stomatal $\left(N S_{\mathrm{L}}=\right.$ mesophyll limitation $\left.\left(\mathrm{MC}_{\mathrm{L}}\right)+B_{\mathrm{L}}\right)$ and total limitation $\left(T_{\mathrm{L}}=N S_{\mathrm{L}}+\right.$ stomatal limitation) to photosynthesis versus $\Psi_{1, \mathrm{pd}}$. Linear regressions for each site are shown for guidance. 'dry', 'intermediate' and 'wet' refer to the three sites of the rainfall gradient, and are indicated at the top left of each plot.

comparing the scaling exponents of the nonlinear regressions between physiological parameters and predawn leaf water potential, and found that trees at the 'wet' site exhibited steeper stomatal control in response to decreasing $\Psi_{1, \mathrm{pd}}$. However, no among-site differences in drought response were observed when $g_{\mathrm{s}}$ was used as an explanatory variable instead of $\Psi_{1, \text { pd }}$ (Fig. 4, Table 4). Although $\Psi_{1, p d}$ is a surrogate of drought intensity, $g_{\mathrm{s}}$ may be a more effective measure of the impact of drought on leaf metabolism, because drought-induced photosynthetic downregulation results from decreases in $\mathrm{CO}_{2}$ availability that follow stomatal closure (Medrano et al. 2002).

\section{Stomatal sensitivity to drought along a rainfall gradient}

We hypothesised that the functional relationships between leaf physiological parameters and $\Psi_{1, p d}$ would not change along the water availability gradient, due to prevailing anatomical, morphological or demographic adjustments at higher hierarchical levels. This hypothesis was largely based on previous observations in $Q$. ilex, made during a 7 year partial throughfall exclusion experiment at the 'intermediate' site of our gradient (Limousin et al. 2009, 2010). This initial hypothesis was partially verified, as LAI more than doubled from the driest to the wettest site (Table 1), in accordance with the ecohydrological equilibrium theory (Eagleson 1982). Eagleson (1982) postulated that trees adjust whole-canopy leaf area rather than leaf physiology in response to climatic variation. Leaf area production has been identified as the primary adjustment to drought in several gradient studies (Gholz 1982; Addington et al. 2006), rainfall manipulation experiments (Brando et al. 2008; Limousin et al. 2009) and model simulations (Nemani et al. 2003). In our case, long-term LAI adjustment was effective between the 'dry' and 'intermediate' sites, for which no differences in stomatal control were observed. However, contrary to our expectations, the relationship between $g_{\mathrm{s}}$ and $\Psi_{1, \mathrm{pd}}$ was steeper at the 'wet' site (Fig. $3 a$ ).

Among-site differences in stomatal sensitivity to drought may have arisen from differences in the sensing and signalling of water deficit (Chaves et al. 2003). Faster stomatal closure at the 'wet' site might be due to a higher leaf concentration of ABA, produced by the roots in response to desiccation. Differential responses to ABA can be related to isohydric vs anisohydric stomatal behaviour (Tardieu and Simonneau 1998). Although isohydric species exhibit relatively constant $\Psi_{1, \min }$, anisohydric species maintain transpiration rate by keeping a constant water potential gradient between soil and leaf. These differences are normally accompanied by a distinct relationship between $\Psi_{1, p d}$ and $\Psi_{1, \text { min }}$, but this relationship did not differ significantly along the rainfall gradient in the present study. Furthermore, long distance chemical signalling in trees is difficult to reconcile with the short-term response of stomata to water deficit (Chaves et al. 2003). Co-regulation of hydraulic and stomatal conductance, mediated by ABA, has been reported in saplings (Aasamaa et al. 2002), but there is little evidence for a role of ABA in stomatal control of water loss in adult Quercus species (Triboulot et al. 1996).

We propose two alternative explanations for our observations. First, individuals from the 'wet' site may exhibit a lower degree of osmotic adjustment to water stress, so that lower turgor pressure and $g_{\mathrm{s}}$ are observed for a given value of $\Psi_{1}$ than in the drier populations. The capacity for osmotic adjustment in response to drought is known to vary between populations of some tree species, depending on local adaptive and acclimatory responses to drought severity (Lopez et al. 2009). However, previous research in $Q$. ilex suggests a limited variability in osmotic adjustment among populations (Sala and Tenhunen 1994; Corcuera et al. 2002). A second explanation is that the relationship between $g_{\mathrm{s}}$ and $\Psi_{1, \mathrm{pd}}$ may respond to differences in hydraulic conductance along the soil-to-leaf pathway (Hubbard et al. 2001). Plant hydraulic models can help to elucidate the response of $g_{\mathrm{s}}$ to soil drought (Sperry et al. 1998). In their simplified form, these models can be expressed as follows (Oren et al. 1999):

$$
g_{\mathrm{s}}=\left(\frac{\Delta \psi}{\mathrm{VPD}}\right) \cdot\left(\frac{k_{\mathrm{s}}}{\mathrm{L}}\right) \cdot\left(\frac{\mathrm{SA}}{\mathrm{LA}}\right),
$$

where stomatal conductance to water vapour $\left(g_{\mathrm{s}}\right)$ is a function of (1) the vapour pressure deficit of the air surrounding the leaf (VPD), (2) the water potential gradient through the soil-to-leaf 
pathway $(\Delta \Psi),(3)$, the sapwood specific hydraulic conductivity $\left(k_{\mathrm{s}}\right)$, (4) the length of the pathway $(L)$, and (5), the ratio of cross-sectional sapwood area to leaf area $(S A / L A)$. In this study, VPD was controlled in the leaf cuvette and was similar among sites. The water potential gradient $(\Delta \Psi)$, represented as the difference between water potential at midday and predawn, was also similar among sites for a given drought intensity (Fig. 2). Therefore it is unlikely that there was a shift in stomatal behaviour from anisohydric to isohydric regulation along the rainfall gradient.

Changes in stomatal sensitivity to drought stress can also result from differences in hydraulic architecture and tree stature. Homeostasis of leaf water status can be achieved through anatomical and morphological adjustments at the whole-plant scale (Maseda and Fernandez 2006). The differences in stomatal control observed in our three $Q$. ilex populations may, therefore, be the result of altered hydraulic architecture in response to drought, which influences the partitioning of carbon resources among leaves, sapwood and rooting networks. Height is an important factor controlling hydraulic architecture during tree ontogeny (Mencuccini et al. 2005). Across our three Q. ilex populations, we observed higher growth rates at the 'wet' site $\left(\sim 7 \mathrm{~cm}\right.$ year $\left.^{-1}\right)$ than at the 'intermediate' $\left(\sim 6 \mathrm{~cm}\right.$ year $\left.^{-1}\right)$ and 'dry' sites $\left(\sim 5 \mathrm{~cm}\right.$ year $\left.{ }^{-1}\right)$, consistently with the ranking of mean canopy heights (Table 1). The greater height and faster growth of trees at the 'wet' site support the hypothesis that hydraulic limitation of stomatal conductance varies across the gradient, suggesting a trade-off between growth rate and tolerance to water stress (Chapin et al. 1993).

The interpretation of physiological, anatomical and morphological changes across populations of our precipitation gradient is complicated by other differences in environmental and structural features that are not necessarily linked with drought but are known to influence hydraulic architecture (Addington et al. 2006). Such a bias is inherent to field studies carried out along climatic gradients. One of the confounding factors in our study was tree age, which was older at the 'wet' site. Tree age modifies hydraulic architecture, by increasing the length of the hydraulic pathway (Magnani et al. 2000). However, age was only partly responsible for taller trees at the 'wet' site, as the growth rate was also higher. Elevation-related differences in minimum temperatures may also have influenced plant regulation of $g_{\mathrm{s}}$. Winter cold is known to be responsible for freezing-induced embolism, which can reduce $k_{\mathrm{s}}$ and sapwood hydraulic conductivity (Cavender-Bares et al. 2005). Finally, the reduction of tree density from the 'dry' to the 'wet' site may have influenced water relations at the stand level. However, it is unlikely that tree density played a substantial role in drought response. First, tree density was shown to have less impact than canopy cover on leaf gas exchange in Q. ilex stands (Moreno and Cubera 2008). Second, lower tree density would more likely reduce water scarcity by limiting competition, which would cause increased sensitivity to drought in the denser stands.

\section{Conclusion}

Collectively, the present results demonstrate that long-term acclimation to drought can result in within-species shifts in leaf physiology, in addition to changes in leaf area index, as part of a co-ordinated strategy to achieve ecohydrological equilibrium. The differences observed in the responses of leaf photosynthetic parameters to long-term water stress are likely to be the result of hydraulic architectural modifications that affect the relationship between stomatal conductance and leaf water potential. Many carbon and water flux models currently employ species-specific relationships between leaf photosynthetic processes and drought. The results of our study in $Q$. ilex suggest that further sensitivity analysis is necessary to quantify the errors that may arise from modelling primary productivity without accounting for within species physiological adjustments to long-term changes in drought frequency and intensity. We recommend that future field research and model development efforts be directed towards furthering our understanding of how hydraulic conductance may be affected by long-term changes in exposure to water stress.

\section{Acknowledgements}

This work is a tribute to Laurent Misson, who initiated this research in 2007. A doctoral research grant to NKM was provided by Agence de l'Environnement et de la Maîtrise de l'Energie (ADEME) and the French Research Agency (ANR), through the Drought+ project (ANR-06-VULN-003-01). J R-C was supported by a post-doctoral fellowship from the Ministerio de Ciencia e Innovación (Spain). Additional support was provided by the European project CARBOEXTREME (EP7-ENV-2008-1, project number 226701). The authors wish to acknowledge the Office National des Forêts (ONF) for help in site selection. We warmly thank David Degueldre, Raquel Rodriguez, Fabien Bach, Elsa Donon and Emmanuel Gritti for help in field measurements and laboratory analysis, as well as Elsa Canard, for conceptual participation.

\section{References}

Aasamaa K, Sober A, Hartung W, Niinemets U (2002) Rate of stomatal opening, shoot hydraulic conductance and photosynthetic characteristics in relation to leaf abscisic acid concentration in six temperate deciduous trees RID A-3816-2008. Tree Physiology 22, 267-276.

Addington RN, Donovan LA, Mitchell RJ, Vose JM, Pecot SD, Jack SB, Hacke UG, Sperry JS, Oren R (2006) Adjustments in hydraulic architecture of Pinus palustris maintain similar stomatal conductance in xeric and mesic habitats. Plant, Cell \& Environment 29, 535-545. doi:10.1111/j.1365-3040.2005.01430.x

Allen CD, Macalady AK, Chenchouni H, Bachelet D, McDowell N, Vennetier M, Kitzberger T, Rigling A, Breshears DD, Hogg EH, Gonzalez P, Fensham R, Zhang Z, Castro J, Demidova N, Lim JH, Allard G, Running SW, Semerci A, Cobb N (2010) A global overview of drought and heat-induced tree mortality reveals emerging climate change risks for forests. Forest Ecology and Management 259, 660-684. doi:10.1016/j.foreco.2009.09.001

Bernacchi CJ, Singsaas EL, Pimentel C, Portis AR Jr, Long SP (2001) Improved temperature response functions for models of Rubiscolimited photosynthesis. Plant, Cell \& Environment 24, 253-259. doi:10.1111/j.1365-3040.2001.00668.x

Bernacchi CJ, Portis AR Jr, Nakano H, von Caemmerer S, Long SP (2002) Temperature response of mesophyll conductance. Implications for the determination of Rubisco enzyme kinetics and for limitations to photosynthesis in vivo. Plant Physiology 130, 1992-1998. doi:10.1104/ pp. 008250

Beyschlag W, Pfanz H, Ryel RJ (1992) Stomatal patchiness in Mediterranean evergreen sclerophylls - phenomenology and consequences for the interpretation of midday depression in photosynthesis and transpiration. Planta 187, 546-553. 
Bota J, Medrano H, Flexas J (2004) Is photosynthesis limited by decreased Rubisco activity and RuBP content under progressive water stress? New Phytologist 162, 671-681. doi:10.1111/j.1469-8137.2004.01056.x

Brando PM, Nepstad DC, Davidson EA, Trumbore SE, Ray D, Camargo P (2008) Drought effects on litterfall, wood production and belowground carbon cycling in an Amazon forest: results of a throughfall reduction experiment. Philosophical Transactions of the Royal Society B: Biological Sciences 363, 1839-1848. doi:10.1098/rstb.2007.0031

Buckley TN, Farquhar GD, Mott KA (1997) Qualitative effects of patchy stomatal conductance distribution features on gas-exchange calculations. Plant, Cell \& Environment 20, 867-880. doi:10.1046/j.1365-3040.1997. $\mathrm{d} 01-128 . \mathrm{x}$

Castro-Diez P, Villar-Salvador P, Pérez-Rontomé C, Maestro-Martinez M, Montserrat-Martí G (1997) Leaf morphology and leaf chemical composition in three Quercus (Fagaceae) species along a rainfall gradient in NE Spain. Trees 11, 127-134. doi:10.1007/PL00009662

Cavender-Bares J, Cortes P, Rambal S, Joffre R, Miles B, Rocheteau A (2005) Summer and winter sensitivity of leaves and xylem to minimum freezing temperatures: a comparison of co-occurring Mediterranean oaks that differ in leaf lifespan. New Phytologist 168, 597-612. doi:10.1111/ j.1469-8137.2005.01555.x

Chapin FS III, Autumn K, Pugnaire F (1993) Evolution of suites of traits in response to environmental stress. American Naturalist 142, S78-S92. doi:10.1086/285524

Chaves MM (1991) Effects of water deficits on carbon assimilation. Journal of Experimental Botany 42, 1-16. doi:10.1093/jxb/42.1.1

Chaves MM, Maroco JP, Pereira JS (2003) Understanding plant responses to drought - from genes to the whole plant. Functional Plant Biology 30, 239-264. doi:10.1071/FP02076

Ciais P, Reichstein M, Viovy N, Granier A, Ogee J, Allard V, Aubinet M, Buchmann N, Bernhofer C, Carrara A, Chevallier F, De Noblet N, Friend AD, Friedlingstein P, Grunwald T, Heinesch B, Keronen P, Knohl A, Krinner G, Loustau D, Manca G, Matteucci G, Miglietta F, Ourcival JM, Papale D, Pilegaard K, Rambal S, Seufert G, Soussana JF, Sanz MJ, Schulze ED, Vesala T, Valentini R (2005) Europe-wide reduction in primary productivity caused by the heat and drought in 2003. Nature $\mathbf{4 3 7}$, 529-533. doi:10.1038/nature03972

Corcuera L, Camarero JJ, Gil-Pelegrin E (2002) Functional groups in Quercus species derived from the analysis of pressure-volume curves. Trees Structure and Function 16, 465-472.

Dunne JA, Saleska SR, Fischer ML, Harte J (2004) Integrating experimental and gradient methods in ecological climate change research. Ecology 85, 904-916. doi:10.1890/03-8003

Eagleson PS (1982) Ecological optimality in water-limited natural soilvegetation systems. 1. Theory and hypothesis. Water Resources Research 18, 325-340. doi:10.1029/WR018i002p00325

Farquhar GD, von Caemmerer S, Berry JA (1980) A biochemical model of photosynthetic $\mathrm{CO}_{2}$ assimilation in leaves of $\mathrm{C}_{3}$ species. Planta 149, 78-90. doi:10.1007/BF00386231

Flexas J, Diaz-Espejo A, Galmés J, Kaldenhoff R, Medrano H, Ribas-Carbo M (2007) Rapid variations of mesophyll conductance in response to changes in $\mathrm{CO}_{2}$ concentration around leaves. Plant, Cell \& Environment 30, 1284-1298. doi:10.1111/j.1365-3040.2007.01700.x

Flexas J, Ribas-Carbo M, Diaz-Espejo A, Galmes J, Medrano H (2008) Mesophyll conductance to $\mathrm{CO}_{2}$ : current knowledge and future prospects. Plant, Cell \& Environment 31, 602-621. doi:10.1111/j.1365-3040.2007. 01757.x

Gholz HL (1982) Environmental limits on aboveground net primary production, leaf area, and biomass in vegetation zones of the Pacific northwest. Ecology 63, 469-481. doi:10.2307/1938964

Grassi G, Magnani F (2005) Stomatal, mesophyll and biochemical limitations to photosynthesis as affected by drought and leaf ontogeny in ash and oak trees. Plant, Cell \& Environment 28, 834-849. doi:10.1111/j.13653040.2005.01333.x
Harley PC, Thomas RB, Reynolds JF, Strain BR (1992a) Modeling photosynthesis of cotton grown in elevated $\mathrm{CO}_{2}$. Plant, Cell \& Environment 15, 271-282. doi:10.1111/j.1365-3040.1992.tb00974.x

Harley PC, Loreto F, Di Marco G, Sharkey TD (1992b) Theoretical considerations when estimating the mesophyll conductance to $\mathrm{CO}_{2}$ flux by analysis of the response of photosynthesis to $\mathrm{CO}_{2}$. Plant Physiology 98, 1429-1436. doi:10.1104/pp.98.4.1429

Hoff C, Rambal S (2003) An examination of the interaction between climate, soil and leaf area index in a Quercus ilex ecosystem. Annals of Forest Science 60, 153-161. doi:10.1051/forest:2003008

Hubbard RM, Ryan MG, Stiller V, Sperry JS (2001) Stomatal conductance and photosynthesis vary linearly with plant hydraulic conductance in ponderosa pine. Plant, Cell \& Environment 24, 113-121. doi:10.1046/ j.1365-3040.2001.00660.x

Keenan T, Sabate S, Gracia C (2010) The importance of mesophyll conductance in regulating forest ecosystem productivity during drought periods. Global Change Biology 16, 1019-1034. doi:10.1111/ j.1365-2486.2009.02017.x

Krall JP, Edwards GE (1992) Relationship between photosystem II activity and $\mathrm{CO}_{2}$ fixation in leaves. Physiologia Plantarum 86, 180-187. doi:10.1111/j.1399-3054.1992.tb01328.x

Lawlor DW, Cornic G (2002) Photosynthetic carbon assimilation and associated metabolism in relation to water deficits in higher plants. Plant, Cell \& Environment 25, 275-294. doi:10.1046/j.0016-8025.2001. 00814.x

Leuzinger S, Luo Y, Beier C, Dieleman W, Vicca S, Körner C (2011) Do global change experiments overestimate impacts on terrestrial ecosystems? Trends in Ecology \& Evolution 26, 236-241. doi:10.1016/j.tree.2011.02.011

Limousin JM, Rambal S, Ourcival JM, Rocheteau A, Joffre R, RodriguezCortina R (2009) Long-term transpiration change with rainfall decline in a Mediterranean Quercus ilex forest. Global Change Biology 15, 2163-2175. doi:10.1111/j.1365-2486.2009.01852.x

Limousin JM, Misson L, Lavoir AV, Martin NK, Rambal S (2010) Do photosynthetic limitations of evergreen Quercus ilex leaves change with long-term increased drought severity? Plant, Cell \& Environment 33, 863-875.

Lopez R, Aranda I, Gil L (2009) Osmotic adjustment is a significant mechanism of drought resistance in Pinus pinaster and Pinus canariensis. Investigacion Agraria-Sistemas Y Recursos Forestales $\mathbf{1 8 ,}$ 159-166.

Magnani F, Mencuccini M, Grace J (2000) Age-related decline in stand productivity: the role of structural acclimation under hydraulic constraints. Plant, Cell \& Environment 23, 251-263. doi:10.1046/ j.1365-3040.2000.00537.x

Maseda PH, Fernandez RJ (2006) Stay wet or else: three ways in which plants can adjust hydraulically to their environment. Journal of Experimental Botany 57, 3963-3977. doi:10.1093/jxb/er1127

Medrano H, Escalona JM, Bota J, Gulías J, Flexas J (2002) Regulation of photosynthesis of $\mathrm{C}_{3}$ plants in response to progressive drought: stomatal conductance as a reference parameter. Annals of Botany 89, 895-905. doi:10.1093/aob/mcf079

Mencuccini M, Hamid H, Korakaki E, Martinez-Vilalta J, Vanderklein D (2005) Limitations to tree height and growth: decoupling the effects of age and size across four species. Comparative Biochemistry and Physiology. Part A, Molecular \& Integrative Physiology 141, S275-S276.

Misson L, Tu KP, Boniello RA, Goldstein AH (2006) Seasonality of photosynthetic parameters in a multi-specific and vertically complex forest ecosystem in the Sierra Nevada of California. Tree Physiology 26, 729-741.

Misson L, Limousin JM, Rodriguez R, Letts MG (2010a) Leaf physiological responses to extreme droughts in Mediterranean Quercus ilex forest. Plant, Cell \& Environment 33, 1898-1910. doi:10.1111/j.13653040.2010.02193.x 
Misson L, Rocheteau A, Rambal S, Ourcival JM, Limousin JM, Rodriguez R (2010b) Functional changes in the control of carbon fluxes after 3 years of increased drought in a Mediterranean evergreen forest? Global Change Biology 16, 2461-2475.

Morales P, Sykes MT, Prentice IC, Smith P, Smith B, Bugmann H, Zierl B, Friedlingstein P, Viovy N, Sabate S, Sanchez A, Pla E, Gracia CA, Sitch S, Arneth A, Ogee J (2005) Comparing and evaluating process-based ecosystem model predictions of carbon and water fluxes in major European forest biomes. Global Change Biology 11, 2211-2233. doi:10.1111/j.1365-2486.2005.01036.x

Moreno G, Cubera E (2008) Impact of stand density on water status and leaf gas exchange in Quercus ilex. Forest Ecology and Management 254, 74-84. doi:10.1016/j.foreco.2007.07.029

Mouillot F, Rambal S, Joffre R (2002) Simulating climate change impacts on fire frequency and vegetation dynamics in a Mediterranean-type ecosystem. Global Change Biology 8, 423-437. doi:10.1046/j.13652486.2002.00494.x

Nemani RR, Keeling CD, Hashimoto H, Jolly WM, Piper SC, Tucker CJ, Myneni RB, Running SW (2003) Climate-driven increases in global terrestrial net primary production from 1982 to 1999. Science 300, 1560-1563. doi:10.1126/science. 1082750

Niinemets U, Tenhunen JD (1997) A model separating leaf structural and physiological effects on carbon gain along light gradients for the shadetolerant species Acer saccharum. Plant, Cell \& Environment 20, 845-866. doi:10.1046/j.1365-3040.1997.d01-133.x

Niinemets U, Cescatti A, Rodeghiero M, Tosens T (2005) Leaf internal diffusion limits photosynthesis more strongly in older leaves of Mediterranean evergreen broad-leaved species. Plant, Cell \& Environment 28, 1552-1566. doi:10.1111/j.1365-3040.2005.01392.x

Niinemets U, Cescatti A, Rodeghiero M, Tosens T (2006) Complex adjustments of photosynthetic potentials and internal diffusion conductance to current and previous light availabilities and leaf age in Mediterranean evergreen species Quercus ilex. Plant, Cell \& Environment 29, 1159-1178. doi:10.1111/j.1365-3040.2006.01499.x

Niinemets U, Diaz-Espejo A, Flexas J, Galmes J, Warren CR (2009a) Importance of mesophyll diffusion conductance in estimation of plant photosynthesis in the field. Journal of Experimental Botany 60, 2271-2282. doi:10.1093/jxb/erp063

Niinemets U, Wright IJ, Evans JR (2009b) Leaf mesophyll diffusion conductance in 35 Australian sclerophylls covering a broad range of foliage structural and physiological variation. Journal of Experimental Botany 60, 2433-2449. doi:10.1093/jxb/erp045

Ogaya R, Penuelas J (2007) Leaf mass per area ratio in Quercus ilex leaves under a wide range of climatic conditions. The importance of low temperatures. Acta Oecologica 31, 168-173. doi:10.1016/j.actao.2006. 07.004

Oren R, Sperry JS, Katul GG, Pataki DE, Ewers BE, Phillips N, Schafer KVR (1999) Survey and synthesis of intra- and interspecific variation in stomatal sensitivity to vapour pressure deficit. Plant, Cell \& Environment 22, 1515-1526. doi:10.1046/j.1365-3040.1999.00513.x
Poorter H, Niinemets U, Poorter L, Wright IJ, Villar R (2009) Causes and consequences of variation in leaf mass per area (LMA): a meta-analysis. New Phytologist 182, 565-588.

Rambal S, Ourcival JM, Joffre R, Mouillot F, Nouvellon Y, Reichstein M, Rocheteau A (2003) Drought controls over conductance and assimilation of a Mediterranean evergreen ecosytem: scaling from leaf to canopy. Global Change Biology 9, 1813-1824. doi:10.1111/j.1365-2486.2003. 00687.x

Rustad LE (2008) The response of terrestrial ecosystems to global climate change: towards an integrated approach. The Science of the Total Environment 404, 222-235. doi:10.1016/j.scitotenv.2008.04.050

Sala A, Tenhunen JD (1994) Site-specific water relations and stomatal response of Quercus ilex in a mediterranean watershed. Tree Physiology 14, 601-617.

Saxton KE, Rawls WJ (2006) Soil water characteristic estimates by texture and organic matter for hydrologic solutions. Soil Science Society of America Journal 70, 1569-1578. doi:10.2136/sssaj2005.0117

Schär C, Jendritzky G (2004) Climate change: hot news from summer 2003. Nature 432, 559-560. doi:10.1038/432559a

Sheffield J, Wood EF (2008) Projected changes in drought occurrence under future global warming from multi-model, multiscenario, IPCC AR4 simulations. Climate Dynamics 31, 79-105.

Somot S, Sevault F, Deque M, Crepon M (2008) 21 st century climate change scenario for the Mediterranean using a coupled atmosphere-ocean regional climate model. Global and Planetary Change 63, 112-126. doi:10.1016/j.gloplacha.2007.10.003

Sperry JS, Adler FR, Campbell GS, Comstock JP (1998) Limitation of plant water use by rhizosphere and xylem conductance: results from a model. Plant, Cell \& Environment 21, 347-359. doi:10.1046/j.1365-3040. 1998.00287.x

Tardieu F, Simonneau T (1998) Variability among species of stomatal control under fluctuating soil water status and evaporative demand: modelling isohydric and anisohydric behaviours. Journal of Experimental Botany 49, 419-432. doi:10.1093/jexbot/49.suppl_1.419

Triboulot MB, Fauveau ML, Breda N, Label P, Dreyer E (1996) Stomatal conductance and xylem-sap abscisic acid (ABA) in adult oak trees during a gradually imposed drought. Annales des Sciences Forestieres 53, 207-220. doi:10.1051/forest:19960204

Warren CR, Adams MA (2006) Internal conductance does not scale with photosynthetic capacity: implications for carbon isotope discrimination and the economics of water and nitrogen use in photosynthesis. Plant, Cell \& Environment 29, 192-201. doi:10.1111/j.1365-3040.2005.01412.x

Zerihun A, Montagu KD, Hoffmann MB, Bray SG (2006) Patterns of below- and aboveground biomass in Eucalyptus populnea woodland communities of northeast Australia along a rainfall gradient. Ecosystems 9, 501-515. doi:10.1007/s10021-005-0155-x 